\title{
Perancangan Pertunjukan Opera Minangkabau Malin Nan Kondang sebagai Alih Wahana Kaba Malin Kundang
}

\author{
Edy Suisno $^{1}$, Iswandi ${ }^{1}$, R.M. Pramutomo ${ }^{2}$, Lili Suparli ${ }^{3}$, \\ Novesar Jamarun ${ }^{1}$ (Penulis Koresponden) \\ ${ }^{1}$ Fakultas Seni Pertunjukan, Institut Seni Indonesia Padangpanjang \\ ${ }^{2}$ Fakultas Seni Pertunjukan, Institut Seni Indonesia Surakarta \\ ${ }^{3}$ Fakultas Seni Pertunjukan, Institut Seni Budaya Indonesia Bandung
}

\begin{abstract}
The Design of Minangkabau Opera Performance, Malin Nan Kondang as the Media Change of Kaba Malin Kundang. The design of the Minangkabau Opera Performance, Malin Nan Kondang as the Media Change of Kaba Malin Kundang is the process of creating the Minangkabau Opera performance, which starts from the reinterpretation of Kaba Malin Kundang. Creating the Minangkabau Opera performance began with research on various interpretations of Kaba Malin Kundang as a starting point for forming new understandings of the kaba. The new interpretation was then created to produce a new play form, which was later given the title Malin Nan Kondang. This new play is the foothold in the stage (spectacle) design that characterizes a Minangkabau Opera performance. The pouring is a form of design starting from play analysis, making scene by scene and placing the opera's supporting aspects, including movement, drumming, and appreciation of acting. The accentuation of the opera is manifested by the use of various Minangkabau traditional arts for the needs of the overall Minangkabau Opera design. The accentuation includes dialogue with drumming, choreography and choirs and dialogue in the form of poetry.
\end{abstract}

Keywords: Kaba Malin Kundang; Malin Nan Kondang's play; Minangkabau Opera

\section{Pendahuluan}

Salah satu kaba (folklore) yang sangat populer dalam sastra Minangkabau adalah Malin Kundang. Kaba Malin Kundang mengisahkan seorang anak laki-laki yang sukses di perantauan, yang kemudian durhaka kepada ibunya. Kisah ini seolah telah menjadi kredo moral yang sangat berpengaruh, tidak hanya di Minangkabau, tetapi juga di wilayah lain di Nusantara; betapa melawan orang tua, terutama ibu adalah representasi kedurhakaan yang dapat diazab serupa batu.
Kaba Malin Kundang bukan hanya menjadi inspirasi seni bertutur (story telling), melainkan juga menjadi titik pijak dalam menciptakan karya-karya baru, baik dalam bentuk genre sastra lain, maupun dalam bentuk karya seni sebagai hasil dari alih wahana (ekranisasi).

Malin Kundang pernah ditafsirkan kembali oleh A.A. Navis dalam sebuah cerpen yang berjudul Malin Kundang Ibunya Durhaka. Dalam cerpen tersebut dikisahkan bahwa betapa Malin Kundang harus mengutuk dirinya sendiri untuk menunjukkan bahwa

\footnotetext{
Alamat korespondensi: Fakultas Seni Pertunjukan, Insititut Seni Indonesia Padangpanjang. Jl. Bahder Johan, Kota Padangpanjang, Sumatera Barat. Email: edysuisno08@gmail.com; iswandi014@gmail.com; rektor@ isipadangpanjang.ac.id.

2 Alamat korespondensi: Fakultas Seni Pertunjukan, Insititut Seni Indonesia Surakarta. Jl. Ki Hajar Dewantara No.19, Jebres, Surakarta, Jawa Tengah. Email: rmpram@yahoo.com.

3 Alamat korespondensi: Fakultas Seni Pertunjukan, Insititut Seni Budaya Indonesia Bandung. Jl. Buah Batu No.212, Cijagra, Lengkong, Kota Bandung, Jawa Barat. Email: jaksun_bdg@gmail.com.
} 
ia telah terlahir dari perut yang salah. Diceritakan pula bahwa ketika Malin Kundang telah terkutuk menjadi batu, maka di Pantai Air Manis tiap senja akan terdengar sayup teriakan kutukan pada ibunya karena telah menanduskan tanah leluhurnya (Novianto, 2017: 3). Selain itu, kaba Malin Kundang juga mengilhami Wisran Hadi untuk diwujudkan dalam bentuk lakon drama dengan judul yang sama, Malin Kundang. Dalam lakon drama ini Wisran Hadi mengkritik sistem matrilinial Minangkabau yang acapkali melahirkan subordinasi laki-laki karena dominasi kaum perempuan. Melalui tokoh Ayah, Wisran akhirnya mengkritik perkawinan eksogami dan menuding perkawinan tersebut sebagai reduksi terhadap fungsi seorang suami sekaligus seorang laki-laki.

Berbagai kreativitas di atas, membuktikan betapa kaba Malin Kundang telah mendorong inisiatif para sastrawan untuk melahirkan paradigma baru, yakni dengan menempatkan posisi ibu (wanita) tidak lagi sebagai figur sentral yang "superior". Sebaliknya, wanita dalam alih wahana kaba Malin Kundang menjadi "antitesa" terhadap posisi ibu, sebagaimana yang dituturkan di kaba Malin Kundang. Sebagaimana diketahui, Ibu dalam kaba Malin Kundang merupakan simpul relasi sosial yang sangat penting. Ibu menjadi penentu dan pemutus dalam banyak hal, terkait dengan kehidupan anggota keluarga perinduannya. Posisi yang demikian penting, membuat perempuan secara normatif sangat dihargai, dihormati, dan dipatuhi. Namun sebaliknya, perempuan juga dituntut untuk memenuhi peran-peran sosial budaya normatifnya (Yuniarti, Rahmadani, 2017: $60)$.

Kehadiran Opera Minangkabau merupakan formulasi seni pertunjukan yang penting dikembangkan di era kekinian. Hal ini mengingat banyaknya keanekaragaman seni yang berkembang di ranah Minangkabau. Keanekaragaman tersebut dapat dilihat dari eksistensi berbagai seni tradisi, baik yang berupa seni tari, seni musik, seni teater, maupun seni suara (folk song). Keragaman seni tradisional Minangkabau tersebut menjadi kekayaan ekspresi kearifan lokal yang dapat dikemas dalam bentuk Opera Minangkabau.

Opera Minangkabau Malin Nan Kondang, diharapkan akan menjadi suatu kreativitas seni pertunjukan yang menimbang aspek didaktis, aspek kritis, dan aspek hiburan dalam satu keutuhan. Suatu bentuk teater yang merupakan pengembangan dari teaterteater yang telah ada yang memiliki daya jual (dalam ranah industri hiburan). Suatu seni pertunjukan (teater) yang tidak sekadar dikukuhkan sebagai pengusung "ideologi estetik" atau dialektika intelektual semata, tetapi sebuah teater yang kontennya lekat dengan keseharian publik terdekatnya, disajikan dengan bahasa tutur yang relatif mudah dicerna oleh multisegmen penonton, tanpa harus mereduksi bobot kecerdasan teksnya.

\section{Pembahasan}

Opera Minangkabau Malin Nan Kondang dirancang dengan konvergensi dan dominasi di atas panggung, sebagaimana konsepsi opera (drama musikal) yang berkembang belakangan ini, yang lebih menekankan aspekaspek musikal. Aspek musikal yang dimaksud tidak bisa dimaknai sebagai penghilangan (negasi) atas verbalitas (percakapan kata), tetapi justru ciri khas Opera Minangkabau diupayakan untuk tetap mempertahankan verbalitas, meskipun verbalitas diletakkan dalam subordinat aspek-aspek musikal.

\section{A. Konsep Perancangan (Holistik)}

Dalam perancangan ini acuan yang dijadikan titik tolak adalah batasan Kristin Fawcett yang mengatakan:

According to Tommasini, the real distinguishing detail a musical and an opera is that in opera music is the driving forvce; in musical theather word come fisrt. (Menurut Tommasini, Perbedaan mendasar musikal dan opera adalah 
dalam opera, musik menjadi kekuatan penggerak; pada teater, musikal dialog lebih utama). (http://mentalfloss. com/article/94879/whats-differencebetween-opera-and-musical).

Opera Minangkabau merupakan upaya untuk menelusuri seni teater baru yang berbeda dengan konsepsi opera dalam batasan opera yang berkembang di Barat (western). Opera Minangkabau tak lepas sama sekali dari pengaruh Barat, terutama dalam penonjolan aspek-aspek musikal, seperti dialog dalam bentuk nyanyian, penghadiran suasana yang bertumpu pada paduan suara (choir), dan gerak tarian untuk mempertegas suasana psikologis para tokoh yang dihadirkan.

Kesadaran kreatif berikutnya yang dijadikan konsep perancangan adalah sikap dan rasionalisasi terhadap kaba Malin Kundang. Persepsi konservatif yang berkembang di masyarakat adalah tokoh Malin Kundang selalu dijadikan ikon kedurhakaan kepada orang tua. Sebaliknya pula, orang tua selalu berada dalam kategori yang suci sehingga seolah harus selalu dibebaskan dari opposite sang anak. Perubahan karakter anak adalah murni dari anak, orang tua (Ibu) dipandang tidak berkontribusi apapun. Dalam konteks ini maka opera Minangkabau mengawali langkah kreatifnya dengan menumbuhkan pertanyaanpertanyaan kritis untuk dijadikan permulaan dalam mendekonstruksi kaba Malin Kundang tersebut. Pertanyaan-pertanyaan baru tersebut adalah di manakah posisi timpang atau minor orang tua sehingga kedurhakaan itu bisa terjadi? Adakah peran aspek-aspek material juga mempengaruhi perubahan karakter dan relasi antara orang tua dan anak? Apakah perlawanan anak (Malin) murni karena keangkuhan menjaga image dan status barunya?

Opera Minangkabau Malin Nan Kondang juga dirancang sebagai alih wahana atas kaba Malin Kundang. Alih wahana sendiri merupakan terminologi yang dilekatkan oleh sastrawan Sapardi Joko Damono sebagai padanan (sinonim) atas terminologi 'ekranisasi'. Ekranisasi sendiri berasal dari kata ecran (Perancis) yang berarti 'layar'. Kritikus sastra, Pamusuk Erneste (1991: 60), menjelaskan batasan ekranisasi sebagai pelayarputihan atau pemindahan dari karya sastra (novel) menuju layar lebar (film). Dalam kaitan ini, Sapardi Joko Damono (2005: 109) menengarai bahwa proses ekranisasi tidak hanya menembus gaya dan genre dalam sastra, tetapi juga menembus tekstual itu sendiri. Itulah sebabnya proses ekranisasi ia namakan sebagai 'alih wahana'. Dengan demikian, terminologi alih wahana memiliki ruang lingkup perwujudan teks sastra (di luar genre drama) menuju realitas seni pertunjukan.

Proses alih wahana dalam perwujudan pertunjukan Malin Nan Kondang ini juga merupakan upaya penafsiran ulang atas kaba Malin Kundang. Penafsiran ulang akan mengacu pada penerapan teori hermeunetik. Secara etimologis, kata hermeneutics berasal dari bahasa Yunani Kuno ta hermeneutika yang merupakan bentuk jamak dari to hermeneutikon yang berarti 'hal-hal yang berkenaan dengan pemahaman dan penerjemahan suatu pesan (Arif, 2008: 178). Kedua kata tersebut merupakan derivat dari kata 'Hermes' yang dalam mitologi Yunani dikatakan sebagai dewa yang diutus oleh Zeus untuk menyampaikan pesan dan berita pada manusia. Pada akhirnya, hermeneutic dibakukan sebagai ilmu atau metode dan teknik memahamai suatu teks pada abad ke-18 M (Arif, 2008: 179). Dalam perkembangannya, teks dalam perspektif hermeneutik harus diperlakukan sama. Kata dan kalimat dalam teks harus mengalami desakralisasi atau dihindarkan dari impresi yang agung (betapapun itu teks agama). Teori ini tidak sepenuhnya akan dirujuk sebagai upaya menemukan metode, tetapi hanya akan dijadikan sebagai 'rambu' dalam menemukan tafsir baru atas kaba Malin kundang yang kemudian akan dialihwahanakan menjadi sebuah lakon drama yang bertajuk Malin Nan Kondang. 
Kegentingan berikutnya adalah memosisikan seni teater tradisional Mingkabau dalam opera Minangkabau. Dalam konteks ini maka randai, sijobang merupakan kekayaan seni lokal yang akan dijadikan tumpuan. Selain itu, opera Minangkabau juga memanfaatkan berbagai seni vokal Minangkabau, seperti dendang simarantang, dendang sirompak, dendang sampelong sebagai bahan dasar penciptaan choir dan lagu dalam dialog. Secara umum, penempatan teater tradisional dan dendang Minangkabau tersebut dijadikan idiom yang memandu pengemasan (formulasi) opera Minangkabau dalam bentuknya yang bersifat kreasi baru tanpa merusak sesuatu yang bersifat adiluhung.

Perancangan Opera Minangkabau Malin Nan Kondang juga dikemas dalam formulasi pertunjukan yang selaras dengan tujuan industri kreatif. John Howkins (2001: 55) menyatakan bawah industri (ekonomi) kreatif adalah kegiatan ekonomi yang input dan outputnya adalah ide atau gagasan. Esensi dari sebuah kreativitas adalah gagasan. Melalui sebuah gagasan, seseorang yang kreatif kemudian dapat memperoleh penghasilan yang sangat layak. Merujuk pada penjelasan Howkins maka ide-ide estetik yang kemudian dituangkan ke dalam karya seni tidak sekadar bertujuan memperkaya khazanah yang bersifat rohani, tetapi juga memberikan timbal balik secara materi. Dengan demikian, ukuran keberhasilan industri kreatif adalah keunggulan ide dalam menciptakan peluang penghasilan.

\section{B. Perancangan Pengadegan}

Perancangan pengadegan (interaksi antartokoh di area panggung) dalam pertunjukan Opera Minangkabau Malin Nan Kondang disusun berdasarkan pada kaidah-kaidah drama musikal atau opera. Pertunjukan opera adalah jenis pertunjukan teater yang pada awalnya hanya mengenal dialog dalam bentuk nyanyian. Segala penuturan para tokoh disampaikan dengan melantunkan sebuah lagu, yang syairnya berisi tentang kesan dan keinginan para tokoh terhadap tokoh-tokoh yang lain. Namun, dalam perkembangan istilah 'opera' akhirnya mengalami perluasan makna. Opera akhirnya sering dipakai sebagai labelitas teater yang dalam penampilannya lebih menonjolkan aspek-aspek musikal dan nyanyian.

Setiap pertunjukan yang dalam pangadegannya para tokoh mengungkapkan penuturan banyak dengan melantunkan lagu maka lazim disebut sebagai opera. Misalnya, Opera Primadona (Teater Koma), Opera Bom Waktu (Teater Koma), Opera Sangkuriang (ISBI Bandung), dan banyak pertunjukan yang lainnya. Pertunjukan-pertunjukan tersebut, selain menggunakan nyanyian, juga masih mempertahankan dialog para tokoh sebagai media komunikasi pesan yang signifikan sehingga proporsinya sama, bahkan lebih banyak dari nyanyian yang dilantunkan para tokoh. Opera, dengan demikian tidak lagi menjadi istilah baku, tetapi hanya label yang mengisyaratkan pentingnya lagu atau nyanyian (dendang) dalam pertunjukan. Dengan demikian, dalam Opera Minangkabau Malin Nan Kondang, kekuatan dialog akan dihadirkan sebagai pengikat terciptanya adegan demi adegan. Adapun perancangan adegan dalam Opera Minangkabau Malin Nan Kondang adalah sebagai berikut:

\section{Adegan Satu}

Adegan satu menampilkan dua sosok penari yang saling melantunkan dendang (lagu). Dua sosok tersebut merupkan metafora dari kekuatan cinta yang menyatu dalam diri tokoh Malin dan kekasihnya, Nilam. Digambarkan dalam adegan ini (dalam gerak dan lagu), Malin tengah mencurahkan perasaan pada Nilam dan kesediaannya untuk tetap bersama sehidup semati. Gerak atau tarian yang ditampilkan pada awalannya adalah gerak-gerak tangan yang melambangkan tumbuhnya rasa cinta secara individual. Gerak kemudian berlanjut dengan tarian secara bersama yang menyiratkan makna berpadunya dua hati, dan ikrar untuk sehidup semati. 


\section{Adegan Dua}

Adegan dua dikreasi sebagai penggambaran masa remaja Malin dan Nilam yang tengah dirundung kesedihan karena di ambang perpisahan. Dialog di antara kedua tokoh tersebut dituturkan dalam bentuk puisi. Pilihan terhadap dialog puitis tersebut merupakan formulasi untuk menajamkan romantisme dan kedalaman kata. Kedua tokoh menghadap frontal ke arah penonton sambil berdialog puitis dengan menggunakan payung. Dipilihnya payung merupakan simbolisasi dari kebersamaan mereka yang tak putus dalam keteduhan, rasa saling melindungi dan mengayomi. Adegan ini diakhiri dengan tarian yang melambangkan ikatan cinta Malin dan Nilam yang tak terpisahkan, sekaligus merupakan transisi menuju adegan berikutnya (adegan tiga).

\section{Adegan Tiga}

Adegan tiga dirancang untuk menggambarkan perpisahan antara Mandeh (Ibu Malin) dengan Malin. Serangkaian pergerakan tokoh disusun untuk menegaskan kepiluan perpisahan yang terjadi. Adegan diawali dengan dialog verbal yang berintikan pada pesan-pesan Mandeh pada Malin yang harus jadi pegangan Malin selama dalam perantauan. Dialog verbal tersebut diakhiri dengan dendang yang dilantunkan oleh Mandeh. Pengadegan pada bagian ini diakhiri dengan kepergian Malin yang tersusun dalam dua pembagian gerak menggambarkan keraguan Malin karena harus meninggalkan mandehnya. Dialog pada bagian ini berganti dengan dialog verbal yang berisi kredo penting yang harus dijadikan panduan Malin dalam memaknai kata 'rantau' bagi seorang lakilaki Minagkabau.

4. Adegan Empat

Adegan empat dirancang untuk menggambarkan sebuah latar sasaran, yakni arena yang diperuntukan untuk berlatih pencak silat. Dalam sasaran tersebut Malin tengah berpamitan pada tokoh Datuk, sebagai pemimpin kaum atau suku. Dalam adegan dialog verbal dituturkan melalui berbagai gerakan-gerakan silat. Setiap satu kalimat dalam dialog, dikreasi dengan satu motif gerakan silat, baik dengan perubahan kuda-kuda, gerakan tangkisan, gerakan pukulan, maupun gerakan-gerakan yang bertujuan mengunci gerakan lawan. Dialog diformat dengan penekanan diksi (laksis) dan dinamik, mengingat setiap kata mengandung pesan-pesan luhur yang harus dipedomani para perantau agar tidak kehilangan prinsip-prinsip hidup selama dalam perantauan. Adegan ini diakhiri serangkaian gerak tepuak galembong untuk memberi penegasan jiwa kesatria dan keteguhan iman.

\section{Adegan Lima}

Adegan lima dirancang untuk menggambarkan situasi kejiwaan hubungan jarak jauh antara Malin dan Nilam. Kondisi jiwa yang mengalamai kegalauan tersebut dihadirkan dalam bentuk Out of Sound (OS), yakni penyampaian dialog tanpa menghadirkan para tokoh di atas panggung. Kehadiran para tokoh (Malin dan Nilam) disimbolkan dalam bentuk tarian yang dibawakan seorang penari laki-laki dan seorang penari perempuan. Gerakan-gerakan yang dilakukan oleh dua penari tersebut memiliki intensitas yang semakin kuat dan semakin bertempo cepat. Area permainan kedua penari tersebut akan dibatasi melalui penggunaan lampu fokus (focus lamp) dan dihidupkan secara silih berganti sesuai dengan dialog yang dibawakan oleh tokoh Malin dan tokoh Nilam. Dialog yang diperdengarkan berbentuk puisi yang terbagi dalam empat bait puisi, yang diperdengarkan secara bergantian.

6. Adegan Enam

Perancangan adegan enam dibuat untuk menggambarkan komplikasi persoalan yang dialami Nilam, yakni saat dia menghadapi teror Datuk Kayo, seorang laki-laki yang meminangnya dengan paksa. Adegan ini diawali dengan pertengkaran Nilam dan 
Datuk Kayo. Susunan pergerakan dan bloking pemeran pada peristiwa ini disusun secara realistic, dengan mengacu pada motif tindakan. Selepas kepergian Datuk Kayo, yang ditandai dengan terpuruknya Nilam dalam kesedihan mendalam, maka penegasan suasana diwujudkan dalam gerak tarian yang mempergunakan kain. Tarian diawali dengan gerakan serempak antara Nilam dan para penari. Selepas tarian serempak tersebut disusul dengan gerakan tarian tunggal (solo) sebagai simbolisasi perasaan Nilam yang sangat terluka akibat teror Datuk Kayo.

\section{Adegan Tujuh}

Adegan tujuh merupakan episodik kepulangan Malin dari perantauan. Adegan ini terbagi dalam beberapa beat (pengelompokan dialog di bawah adegan), yakni beat pertemuan antara Malin dan Nilam, beat kehadiran Mandeh yang menghendaki Malin menjauhi Nilam, dan beat Datuk yang menasihati Mandeh agar mendukung jalinan kasih antara Malin dan Nilam. Perancangan adegan keseluruhan beat tersebut disusun dengan pendekatan akting yang realistik. Dialog dituturkan dengan memberi pendekatan pada kebutuhan perubahan emosi dalam karakter. Pergerakan para pemeran didasari oleh motif tindakan. Semuanya dikemas dalam laku keseharian, terkecuali pada beat pertemuan antara Datuk dan Mandeh yang dirancang dengan konfigurasi gerak tari. Tarian tersebut dirancang untuk menciptakan penegasan dinamika dalam alur atau jalan cerita.

\section{Adegan Delapan}

Perancangan adegan delapan merupakan penggambaran titik balik karakter Mandeh. Adegan ini terbagi dalam dua beat, yakni beat usaha Malin dalam meyakinkan Nilam bahwa cintanya yang tak berubah dan beat perubahan sikap Mandeh yang akhirnya merestui jalinan kasih antara Malin dan Nilam. Adegan ini menggunakan dialog verbal dan dendang yang dilantunkan
Mandeh saat mengutarakan persetujuanya pada Malin untuk meminang Nilam. Adegan diakhiri dengan berkumpulnya semua tokoh untuk mengadakan pesta pernikahan Malin dan Nilam.

\section{Perancangan Pemeranan (Seni Peran)}

Gaya pemeranan diwujudkan dengan lakuan (aksi) yang mencapai "kewajaran". Penampilan yang wajar adalah bentuk lakuan yang mengutamakan pentingnya penghayatan. Usaha mencapai penghayatan tersebut melalui dua tahapan lakuan (sebagaimana dilansir Stanislavsky), yakni tahap "menghadirkan peran" dalam diri si pemeran dan tahap menampilkan "kehadiran" tersebut dalam instrumen pemeranan yang berwujud tubuh dan suara. Yudiaryani (2002: 168) menyebutkan bahwa setidaknya ada enam persyaratan yang harus dimiliki calon aktor (aktor pemula) agar mampu menyempurnakan keaktorannya, yakni hadir dalam lakuan yang sanggup meyakinkan penonton (sebagaimana tujuan lakuan dalam metode pemeranan Stanislavsky). Keenam persyaratan tersebut, yaitu:

"Pertama, aktor harus memiliki fisik yang prima, fleksibel, dan vokal yang terlatih. Kedua, aktor harus mampu mengobservasi kehidupan sehingga mampu memperkaya lakuannya. Ketiga, aktor harus menguasai psikisnya sehingga mampu menghadirkan imajinasinya. Keempat, aktor harus mengusai lakon secara tepat. Kelima, aktor harus memiliki konsentrasi yang tinggi terhadap lakuan yang dimainkannya. Keenam, aktor harus memiliki kesanggupan untuk mengasah kemampuannya secara terus-menerus".

Secara umum, pencapaian gaya pemeranan pada penampilan tokoh-tokoh Opera Minangkabau Malin Nan Kondang (Tokoh Malin, Nilam, Mandeh, dan Datuk Kayo) harus sanggup memproyeksikan suatu keaktoran yang mampu menyatukan karakter keseharian yang dimiliki pemeran dengan 
kebutuhan karakter tokoh yang diperankan. Pencapaian tersebut akan ditandai dengan keberhasilan pemeran dalam melibatkan dirinya (sebagai pencipta karakter) pada situasi dan kondisi baru yang dialami tokoh dalam naskah. Dengan demikian, proyeksi lakuan yang akan ditempuh dalam pencapaian gaya pemeranan tokoh-tokoh Malin Nan Kondang bukan dalam kapasitas untuk menjadi orang lain, melainkan merupakan penyesuaian terhadap situasi dan kondisi baru tersebut, melalui potensi dan kekayaan batin yang secara privat telah dimiliki oleh pemeran. Inilah yang dalam istilah Eka D. Sitorus lazim disebut sebagai pendekatan presentasi.

Eka D. Sitorus (2002: 22) menjelaskan bahwa pemeranan gaya presentasi adalah laku yang mengutamakan identifikasi antara jiwa si aktor dan jiwa si karakter, sambil memberi kesempatan kepada tingkah lakunya untuk berkembang. Tingkah laku yang dimaksud adalah pengembangan laku dalam imajinasi yang berasal dari situasi-situasi yang diberikan penulis lakon. Pengembangan laku tersebut akan dihidupkan melalui transformasi pengalaman-pengalaman yang dimiliki pemeran untuk disesuaikan dengan karakter tokoh yang ada dalam lakon. Hal tersebut diproses sampai terbentuknya motivasi yang jelas dalam laku. Indikator penting dari tercapainya akting presentasi adalah pencapaian kecenderungan psikologi tokoh menjadi bagian yang menyatu dengan psikologi pemeran. Hal ini akan tergambar pada isian dialog yang diucapkan, ekspresi yang natural, dan gesture yang terlihat proporsional. Inilah yang menjadi esensi gaya akting presentasi yang dihadirkan dalam perwujudan tokoh-tokoh dalam Opera Minangkabau Malin Nan Kondang.

\section{Perancangan Tata Artistik (Setting, Make Up, Costume, Lighting)}

Elemen terpenting berikutnya yang penting dalam pertunjukan opera adalah penataan artistik. Secara umum, penataan artistik merupakan perwujudan keseluruhan unsur-unsur pemanggungan yang diperlukan untuk menggambarkan latar dan petistiwa pada sebuah pementasan (Harymawan, 1984: 67). Unsur-unsur yang dimaksud adalah segala sesuatu yang bersifat visual di atas panggung dengan pemaknaan tertentu, sesuai dengan penafsiran para kreator terhadap teks lakon. Unsur-unsur tersebut meliputi: penataan setting, penataan kostum dan make up, penataan lampu, dan penataan properti.

Penataan setting (background) dalam opera Minangkabau Malin Nan Kondang diwujudkan dengan mengacu dan memedomani kebutuhan format opera Minangkabau secara keseluruhan. Formulasi itu adalah tersusunnya latar cerita yang mampu bergerak secara episodik yang mengharuskan pergantian latar waktu dan tempat yang dapat berpindah-pindah secara cepat. Latar tempat yang berpindah-pindah tersebut adalah keharusan yang dituntunkan naskah lakon yang memiliki peristiwa di beberapa tempat. Tempat tersebut, antara lain sasaran, halaman rumah Malin, jalanan, halaman rumah gadang, dan lautan lepas. Merujuk hal ini maka formulasi setting dalam Opera Minangkabau Malin Nan Kondang menggunakan berbagai jenis setting, antara lain; pertama, adanya jenjang-jenjang di kanan-kiri panggung, sebagai simbolisasi atas keberadaaan rumah tinggal. Kedua, berbagai tempat yang divisualisasi dengan imageimage dengan menggunakan multimedia, yang menggambarkan lautan, hutan, rumah gadang, dan lautan lepas. Adapun jenis setting yang lain digambarkan dalam bentuk nyayian, terutama setting yang menjelaskan situasi tanah rantau.

Penataan kostum dan rias (make up) dalam opera Minangkabau Malin Nan Kondang dirancng dengan memedomani karakter para tokoh dalam naskah lakon. Karakter para tokoh tersebut ditelusuri dari berbagai identifikasi perwatakan, baik secara fisiologis (fisik), psikologis (kejiwaan), maupun sosiologis (status sosial). Selain itu, gaya kostum yang dipilih juga dimodifikasi dalam sentuhan tren hari ini untuk memberi daya tarik secara 
visual. Adapun kostum dan rias tersebut meliputi: kostum dan rias tokoh Malin saat masih hidup sederhana dan saat sudah pulang dari perantauan; kostum dan rias tokoh Mandeh saat masih hidup sederhana ataupun setelah menjadi orang kaya baru; kostum dan rias tokoh Nilam yang selalu dalam keadaan miskin; kostum dan rias tokoh Datuk, yang merupakan pemimpin suatu kaum atau suku; kostum dan rias tokoh Datuk Kayo yang dikenal sebagai saudagar yang sangat kaya. Secara teknis, aplikasi tata rias dilakukan dengan mempertimbangkan anatomi wajah dan usia sebenarnya para pemeran.

Penataan lampu dalam opera Minangkabau Malin Nan kondang dirancang dengan menerapkan konsep penghadiran ruang yang bersifat cepat. Perpindahan ruangyang bersifat cepat tersebut merupakan penyiasatan atas latar cerita dalam naskah lakon yang juga berpindah-pindah secara cepat. Penempatan lampu yang menggambarkan ruang secara cepat tersebut juga difungsikan untuk menciptakan garis dan lingkar area permainan para tokoh yang sedang dimainkan para pemeran. Penataan lampu juga difungsikan untuk mempertegas suasana dan menciptakan angle peristiwa, terutama untuk pergerakan penari dan adegan-adegan yang tidak sepenuhnya bersifat 'puitik'. Adapun lampulampu yang dipergunakan adalah lampu fresnel, lampu par, dan lampu general.

Perancangan tata properti dalam opera Minangkabau Malin Nan Kondang hanya

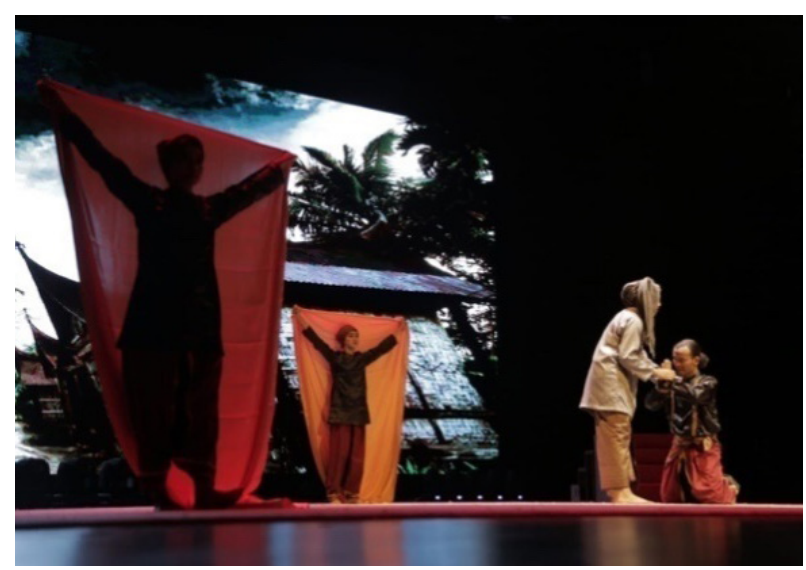

Gambar 1. Setting pertunjukan Opera Minangkabau Malin Nan Kondang tampak depan. Sumber: Iswandi. dirancang untuk satu jenis properti, yaitu properti yang melekat sebagai bagian dari kostum. Properti tersebut adalah sebilah keris yang dipakai Datuk Kayo dan topi caping yang dipakai oleh tokoh Nilam. Sementara itu, jenis properti yang menjadi bagian dari setting (Set-property) tidak dirancang karena setting dalam Opera Minangkabau Malin Nan Kondang dikreasi secara minimalis dan simbolis.

\section{E. Perancangan Tata Iringan dan Ilustrasi}

Aspek musik dalam perancangan ilustrasi Opera Minangkabau Malin Nan Kondang dirancang dengan mengacu pada alur musik (music plot). Alur musik adalah penempatan ilustrasi dengan berpedoman pada kebutuhan aksentuasi suasana (mood). Indikasi yang digunakan sebagai alat ukur pada bagian yang perlu mendapat aksentuasi musik tersebut adalah adanya peningkatan ketegangan (suspense) dalam alur dan menguatnya tekanan psikologis pada para tokoh yang dimainkan para pemeran.

Jenis instrumen yang digunakan adalah berbagai alat musik tradisional, seperti bansi, saluang, sampelong, dan alat musik barat, seperti biola serta piano. Selain itu, juga digunakan ilustrasi yang berbentuk vokal paduan suara (choir) dan duet vokal female. Lagu-lagu (dendang) yang dinyanyikan untuk kepentingan ilustrasi tersebut, antara lain dendang simarantang, dendang sijobang, dendang buaian, dendang sirompak, dan dendang-dendang kreasi baru sebagai pengembangan dari dendang yang telah mengakar di budaya Minangkabau.

Jenis perancangan musik untuk kepentingan iringan dibuat dengan mengacu pada jenis transisi adegan dan ritme gerak pemeran ataupun penari. Selain itu, iringan musik juga disajikan untuk memberi impresi suasana awal sebuah peristiwa atau adegan. Dengan demikian, keberadaan iringan juga mempertimbangkan kebutuhan dramatik pertunjukan secara keseluruhan. Adapun alat musik yang digunakan sebagai iringan meliputi talempong, gandang, dan sarunai. 


\section{F. Perancangan Tata Tari (Koreografi)}

Perwujudan gerak tari dalam Opera Minangkabau Malin Nan Kondang memiliki dua pemaknaan penting. Pertama, gerak merupakan penanda atas impresi-impresi keminangkabauan yang dicerminkan dalam pola-pola gerak silat, yang selama ini menjadi pola dasar gerak tari tradisi Minangkabau. Kedua, gerak tari tersebut merupakan simbolisasi atas peristiwa demi peristiwa yang menimbulkan efek-efek dramatik di atas panggung.

Gerak bagi kebutuhan impresi keminangkabauan dihadirkan pada transisi adeganadegan yang mengetengahkan dialog dua tokoh. Adapun gerak-gerak yang dirancang untuk kebutuhan aksentuasi emosi dan jiwa tokoh secara personal, dilakukan dalam bentuk gerak-gerak yang menggunakan idiomidiom gerak tari moderen (kontemporer). Gerak-gerak untuk aksentuasi emosi dan kejiwaan personal ini juga dilengkapi dengan kain sebagai hand property.

Tempo dan irama gerak disesuaikan dengan kebutuhan dinamika pertunjukan. Formulasinya mengacu pada pencapaian secara paralel dan pencapaian secara paradoks. Pada musik yang paralel maka situasi dramatik yang tinggi akan diimbangi dengan ritme musik yang cepat, sementara pada musik yang bersifat paradoks, gerakgerak yang menggambarkan kesedihan akan ditegaskan dengan musik piano yang ritmis.

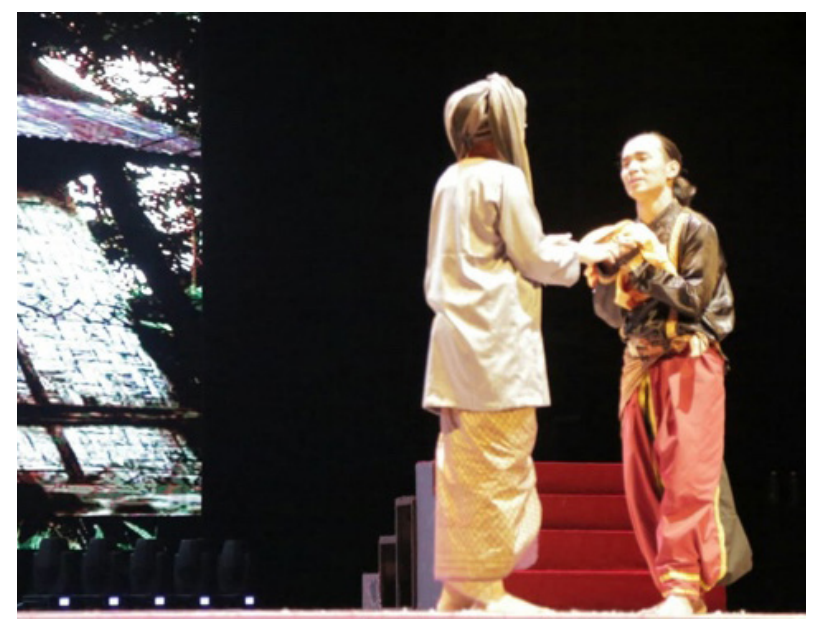

Gambar 2. Alat-alat musik dalam Opera Minangkabau Malin Nan Kondang. Sumber: Iswandi.

\section{G. Perwujudan Gaya dan Konvensi Opera Minangkabau}

Gaya merupakan cara kreator untuk menyatakan dirinya, Pertanyaan diri tersebut membentuk suatu ciri-ciri pemanggungan yang kemudian disepakati menjadi aturan pemanggungan. Inilah yang menjadi esensi terbentuknya konvensi sebuah pertunjukan. Dalam perwujudan Opera Minangkabau Malin Nan Kondang, maka perancang menelusuri berbagai spesifikasi yang telah menjadi konvensi opera secara umum. Merujuk batasan yang ada maka sebuah pertunjukan opera hanya akan melengkapi identitasnya jika dalam ekspresinya aspek-aspek nyanyian (song) menjadi elemen yang dominan. Bahkan secara konservatif, opera sesungguhnya adalah bagian dari gaya pertunjukan yang sama sekali telah meniadakan dialog katakata (ucapan) dan menggantikannya dengan dialog dalam nyanyian. Meskipun demikian, kerangka praktik yang dituangkan dalam Opera Minangkabau tidak dimaksudkan untuk mencipta Opera Minangkabau dalam pengertian yang konservatif. Dalam Opera Minangkabau, dialog dalam bentuk ucapan menjadi bagian yang masih dihadirkan, bahkan memiliki kekuatan yang setara dengan nyanyian.

Selain itu, perwujudan Opera Minangkabau juga mengeksplorasi gaya pertunjukan yang diperkaya dengan berbagai capaian pertunjukan. Capaian tersebut adalah

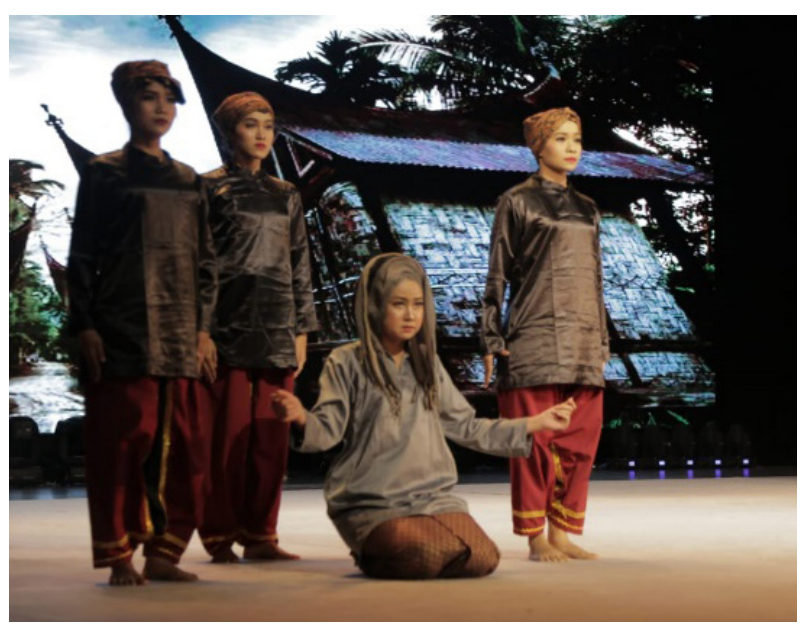

Gambar 3. Adegan salah satu tarian dalam Opera Minangkabau Malin Nan Kondang. Sumber: Iswandi. 
dihadirkannya berbagai tarian rampak dan penuturan yang menggunakan puisi sebagai gaya dialog para tokoh dalam lakon Malin Nan Kondang. Secara lengkap, berbagai penawaran untuk perwujudan konvensi Opera Minangkabau Malin Nan Kondang adalah sebagai berikut:

\section{Penggunaan Puisi}

Aplikasi dialog puisi ini disajikan dalam adegan pembuka (introduksi) antara Malin dan Nilam untuk menggambarkan besarnya cinta di antara dua insan tersebut, yang telah dijalin sejak mereka menginjak usia remaja. Adegan lain yang menggunakan dialog puisi, dapat dilihat dalam adegan lima, saat Malin dan Nilam menyuarakan isi hatinya ketika mereka harus menjalin hubungan kasih jarak jauh, yang dalam pertunjukan dihadirkan dalam bentuk suara (voice over). Penggalan dialog puisi tersebut dapat dibaca dari kutipan dialog di bawah ini.

MALIN : Nilam, kau masih menderu di antara kerinduanku pada secangkir kawa daun yang nyaris membasi. Setiap ambang fajar, aku baru mulai mengatupkan mata, dengan jiwa rapuh tanpa genggaman jari lentikmu. Di setiap deras hujan, aku berusaha bangkit dari kematian demi air mata yang pernah kau simbahkan di bahuku.Demi isakmu untuk menagihku kembali. Ya, lelaki kecil yang teramat sederhana ini akan pulang. Pulang untuk berteduh dan lelap di hatimu."

NILAM : "Aku masih berbaring di antara rinai dan kabut. Berusaha berlari di antara pematang retak. Tapi bibirku selalu begetar di antara butiran air mataku yang menitik, saat namamu kusebut dalam doa menjelang tidur. Aku jatuh berulang, tapi sebait bisikan hati yang kau pahat telah membuat kakiku selalu kokoh. Dan ketika kokok ayam mengetuk fajar, langit biru selalu melukis hal yang sama: penantianku yang tak terbeli, sekalipun napasku koyak oleh kemalangan yang tiada putus. Pulanglah Malin, sekalipun yang kupunya hanya air mata."

2. Kedudukan Koreografi dalam Pertunjukan Koreografitaridirancanguntukmemberikan aksen Minagkabau pada keseluruhan sajian. Tarian dibawakan secara perorangan ataupun kelompok. Pola dan motif gerak dirangkai dengan berpijak dari gerak silat dan langkah energik, sebagaimana umumnya tari tradisi Minangkabau. Tarian ini menjadi determinan karena pola gerak dan langkahnya dibutuhkan sebagai pengisi dan penanda tempo nyanyian, baik yang dibawakan secara choir maupun duet. Secara umum, gerak tari ini berfungsi sebagai aksentuasi kejiwaan dan emosi karakter para tokoh, sekaligus menjadi dinamisator berbagai transisi ruang dan waktu yang dalam pertunjukan ini berjalan cukup cepat.

3. Penempatan Dialog dalam Dendang Penempatan dialog dengan lagu ini diaplikasikan pada berbagai peristiwa (adegan) yang menimbulkan tekanan dan pukulan psikis serta emosi para tokoh, antara lain: dialog antara Mandeh dan Malin yang menggunakan dendang anak babuai; monolog nilam yang menggunakan dendang sampelong; saat Mandeh bertemu Malin sepulang dari perantauan yang berdialog dengan dendang sirompak. Sebelumnya, lewat tarian duet para penari juga berdialog dengan menggunakan dendang ratok sebagai pembuka pertunjukan. Secara menyeluruh, batangan alur dalam Opera Minangkabau Malin Nan Kondang sangat ditentukan oleh dendang, baik untuk kepentingan ilustrasi maupun untuk kepentingan dialog antar tokoh.

4. Penggunaan Epilog (Introduksi) Sebagai introduksi, dendang Si Jobang dilantunkan sebagai salam pembuka, setelah pertunjukan dibuka dengan video 
pendek yang mengisahkan masa kecil Malin dan Nilam. Alunan Si Jobang yang ritmis dan jenaka difungsikan sebagai media pengakrab tontonan. Alunan Si Jobang tersebut dibawakan secara berduet oleh vokalis wanita.

5. Penggunaan Videografi dan Gambar (Image) Proses digitalisasi dalam Opera Minangkabau Malin Nan Kondang dirancang melalui penciptaan fotografi dan videografi. Penggunaan videografi dibuat untuk penggambaran masa kecil Nilam dan Malin, yang menekankan pada eratnya persaudaraan mereka dan berbagai landscape alam serta lingkungan Minangkabau di masa lalu. Sementara itu, penggunaan fotografi editing dirancang untuk menegaskan berbagai latar peristiwa, baik yang berangkat dari latar geografi, latar arsitektur, maupun kekayaan flora di Minangkabau.

\section{H. Metode Perancangan}

Metode perancangan adalah cara kerja kreator seni pertunjukan (teater) yang diawali dari penafsiran naskah lakon sampai dengan perwujudan pentas. Cara-cara penyutradaraan ini dimulai dari sasaran-sasaran yang bersifat pemahaman sampai pada penataan aspekaspek pemanggungan dengan berpedoman pada gaya pementasan yang dipilih. Anirun (2002:115) menjelaskan bahwa proses kreatif penyutradaraan secara umum terbagi dalam empat langkah kreatif yang meliputi: tahap mencari-cari; tahap memberi isi; tahap pengembangan; tahap pemantapan. Dengan mengacu pada metode tersebut, maka perancangan Opera Minangkabau Malin Nan Kondang dibuat melalui penerjemahan baru yang disesuaikan dengan perancangan Opera Minangkabau.

1. Eksplorasi Spektakel (Interpretasi Naskah) Tahap eksplorasi spektakel Opera Minangkabau Malin Nan Kondang merupakan rangkaian kreativitas yang bersifat kognitif untuk mencari kemungkinan-kemungkinan visual, baik dalam bentuk penyusunan pola lantai pemeranan, pembuatan desain artistik, maupun penyusunan partitur musik. Aplikasi konkret dari tahapan ini adalah analisis terhadap lakon, baik secara individu melalui dukungan riset, observasi, studi pustaka maupun dialog dua arah, yakni antara sutradara dan penulis naskah; sutradara dan pemain, sutradara dan penata artistik; sutradara dan penata musik. Riset dalam perancangan ini dilakukan dengan mendokumentasikan beberapa artefak Minangkabau dan melakukan wawancara dengan para penggiat seni budaya yang pernah merevitalisasi cerita rakyat Malin Kundang, seperti Suhendri dari Sanggar Noktah dan Mahatma Muhammad dari Komunitas Seni Nan Tumpah, keduanya di Padang. Langkah kerja berikutnya adalah perancangan naskah lakon yang dikuti dengan penafsiran struktur lakon melaui reading yang dilakukan secara kolektif. Reading tersebut juga bertujuan untuk menjajaki kemampuan pemeran dalam kaitannya dengan tafsir pada tokoh, lebih khusus lagi pada pencarian karakter suara. Di luar proses kerja tersebut, tahap mencaricari dilakukan dengan berbagai latihan dasar teater. Pelaksanaan latihan dasar teater tersebut diarahkan untuk mencari kemungkinan-kemungkinan bagi gestur, analogi-analogi peran, dan menumbuhkan keterkaitan emosi terutama antarpemain. Bentuk latihan dasar tersebut antara lain: eksplorasi motif-motif gerak, olah rasa lewat pemaparan tema-tema tertentu, bernyayi bebas, dan berbagai latihan pernapasan.

2. Memberi Isian Spektakel (Penciptaan Peristiwa)

Tahap memberi isian spektakel merupakan cara kerja perancangan untuk mengembangkan aspek-aspek pemahaman lakon menuju pada aspek-aspek perwujudan visual. Pada tahap ini interpretasi lakon Malin Nan Kondang diarahkan untuk memberikan dorongan semua pendukung (terutama pemeran) dalam mewujudkan akting verbal ataupun nonverbal berdasarkan desain akting yang bersifat 
global, yang telah disepakati sebelumnya. Penemuan-penemuan yang masih bersifat kasar tersebut kemudian diolah untuk mendapatkan penekanan-penekanan yang mampu menggambarkan inti peristiwa, perubahan suasana, dan progresi emosi tokoh-tokohnya. Penekanan-penekanan tersebut akan dihadirkan melalui penegasan pada sisi ekspresi mimik, impresi pada keseluruhan akting pemeran, laku yang memperlihatkan motivasi, dan penyikapan terhadap areal permainan. Aplikasi pada metode ini direalisasikan pada latihan pencarian bloking, improvisasi-improvisasi di luar desain akting, serta konfigurasi gerak tari yang dijadikan pedoman. Latihan tersebut pada dasrnya adalah kretivitas untuk menciptakan peristiwa atau suasana.

3. Pengembangan Spektakel (Penciptaan Dramatik)

Tahap pengembangan merupakan usaha kreator Opera Minangkabau Malin Nan Kondang dalam mengarahkan para pemeran dan para penari untuk mewujudkan movement, gesture, bussines act, dalam bentuk lakuan atau gerak yang sudah memperlihatkan penghayatan. Para pendukung tersebut dibimbing untuk merasakan situasi dalam diri tokoh atau suasana yang diperankan melalui bentuk akting dan gerak yang terlihat meyakinkan. Secara konkret, bentuk latihan Opera Minangkabau Malin Nan Kondang yang dilakukan dalam membangun keyakinan tersebut adalah latihan-latihan kolaboratif yang disertai pembangunan imajinasi terhadap latar cerita, kesadaran ruang, kesinambungan antara aksi dan reaksi, serta posisi kejiwaan pemeran atau penari yang memperlihatkan empati.

4. Pemantapan Spektakel (Harmoni)

Tahapan pemantapan merupakan kerja perancangan untuk menampilkan lakon Malin Nan Kondang secara utuh. Orientasi latihan diarahkan pada perhitungan irama, tempo, dan dinamika. Pusat konsentrasinya adalah pencapaian musikalitas dalam pementasan. Musikalitas tersebut disusun secara berulang-ulang (melalui latihan dari awal hingga akhir lakon) dengan mengacu pada pembenahan ketegangan demi ketegangan, timing pada perubahan suasana, lompatan-lompatan emosi tokoh, dan lambat-cepatnya dialog antartokoh. Pada tahap ini respons terhadap ruang dan dukungan ilustrasi musik terhadap suasana demi suasana, sudah mulai dihadirkan dalam visualisasi yang masih global. Tujuan pengadaan set-dekor dan ilustrasi yang masih belum permanen ini adalah untuk mematangkan gestur pemain, membakukan jarak tempuh movement, dan menyeleksi berbagai unsur artistik serta musikalitas agar tercapai harmoni dalam pementasan.

\section{Penutup}

Perancangan Opera Minangkabau Malin Nan Kondang secara menyeluruh bertumpu pada tiga orientasi kreativitas perwujudan pertunjukan atau pementasan. Pertama, perancangan Opera Minangkabau Malin Nan Kondang merupakan kreativitas dalam mencipta Opera Minangkabau, yang berpedoman pada pertimbangan aspek pemenuhan dan penemuan estetika baru di satu sisi, dan pertimbangan pada aspek kemudahan penerimaaan penonton dalam mengapresiasi pementasan di sisi yang lain. Formulasi atas dua pedoman ini menjadi kepaduan yang menghadirkan kekuatan dalam pementasan.

Orientasi kedua dalam perancangan Opera Minangkabau Malin Nan Kondang adalah pertimbangan pada kepaduan antara idiomidiom seni-seni tradisional Minangkabau dengan idiom-idiom opera yang secara representasional memang telah lahir dan tumbuh dalam seni drama musikal di Barat (Western). Dalam konteks ini maka verbalitas (dialog dalam percakapan kata) sebagai kekuatan teater tradisional Minagkabau tetap diakomodasi secara signifikan dalam pementasan. Kekuatan beberapa konvensi 
opera dari Barat tersebut diformulasi dalam keutuhan yang menyatu secara bulat dengan idiom-idiom seni tradisional (Minagkabau) menjadi identitas dan kekhususan dalam Opera Minangkabau Malin Nan Kondang.

Orientasi ketiga adalah aplikasi alih wahana yang bertumpu pada kerja penafsiran ulang atas Kaba Malin Kundang agar lebih rasional, lebih berimbang, dan dijauhkan dari pesan-pesan doktriner. Tafsir ulang tersebut ditekankan pada paradigma baru bahwa kenakalan atau kedurhakaan anak tidaklah murni sebagai kesalahan anak, tetapi juga kegagalan orang tua dalam mengintensifikasi pendidikan pada anak, dan juga buah dari mainstream lingkungan yang hanya mengukur segala sesuatu atas dasar materi atau kebendaan.

\section{Kepustakaan}

Anirun, Suyatna. 1991. Menjadi Aktor: Pengantar Akting untuk Panggung dan Sinema. Bandung: STSI Press.

Arif, Syamsudin. 2008. Orientalis dan Diabolisme Pemikiran. Jakarta: Gema Insani Press.

Damono, Sapardi Djoko. 2005. Pegangan
Penelitian Sastra Bandingan. Jakarta: Pusat Bahasa.

Djamaris, Edward. 2002. Pengantar Sastra Rakyat Minangkabau. Jakarta: Yayasan Obor Indonesia.

Erneste, Pamusuk. 2008. Novel dan Film. Jakarta: Nusa Indah.

Krishna, Eva. 2016. Legenda Malin Kundang dalam Perspektif Feminisme. Jurnal Balai Bahasa Sumatera Barat.

Harymawan, RMA. 1984. Dramaturgi. Bandung: CV Rosda.

Howkins, J. 2005. The Creative Economy: Knowledge-Driven Economic Growth. India: Jodhpur.

Pavis, Patrice. 1982. Languages of Stages. Essays in the Semiology of the Theatre. New York: Performing Arts Journal Publications.

Yudiaryani. 2000. Panggung Teater Dunia. Yogyakarta: Pustaka Godho Suli.

Yuniarti, Rahmadani. Nilai Edukasi Mitos dan Relevansinya dengan Penanaman Nilai pada Keluarga Minangkabau Kontemporer: Tinjauan Awal. Jurnal Antropologi: Isu-Isu Sosial Budaya. Juni 2017. Vol. 19 (1). 